\title{
Ecological relationships between feather mites (Acari) and wild birds of Emberizidae (Aves) in a fragment of Atlantic Forest in northeastern Brazil
}

\author{
Rachel M. de Lyra-Neves ${ }^{1}$ Ângela M. Isidro de Farias ${ }^{2} \&$ Wallace R. Telino-Júnior ${ }^{1}$
}

${ }^{1}$ Departamento de Ecologia e Biologia Evolutiva, Universidade Federal de São Carlos. Endereço para correspondências: Rua 102, número 136, Jardim Paulista, 53407-220 Paulista, Pernambuco,Brasil.E-mail: rmlneves@msn.com; telinojr@msn.com

2 Departamento de Zoologia, Universidade Federal de Pernambuco. Avenida Professor Moraes Rego 1235, Cidade Universitária, 50670-420 Recife, Pernambuco, Brasil. E-mail: amif33@hotmail.com

\begin{abstract}
The objective of this study was to investigate feather mites on birds of the Family Emberizidae, to collect data on the ecological ectoparasite-host relationship and infestation level. A sum of 94 birds of 9 species was captured at the Refúgio Ecológico Charles Darwin, Igarassú, Pernambuco, Brazil, from August 1996 to July 1997. Five genera of mites from the superfamily Analgoidea were identified: Analges Nitzsch, 1818; Mesalgoides Gaud \& Atyeo, 1967; Pterodectes Robin, 1877; Proctophyllodes Robin, 1877 and Trouessartia Canestrini, 1899. Among the 94 birds examined, 92 (97,87\%) were infested. Regarding the prevalence, it was observed that the genera with higher percentage were, respectively, Pterodectes (88,04\%), Proctophyllodes (56,52\%) and Trouessartia (45,65\%).
\end{abstract}

KEY WORDS. Analgoidea, ecology, infestation, Passeriformes.

Feather mites belong to the Order Acariformes, Suborder Astigmata, Groups Psoroptidia and Analgoidea (GAUD \& ATYEO 1996). According to PHILIPS (1993), they live between the barbs on the ventral surface of contour, wing, and tail feathers. However, during large infestations they may expand to the body skin (PhiLIPs 1993). Feather mites live in intimate association with the feathers, from which they obtain food.

PHILIPs (1993) states that when in excess, feather mites move to the bird skin causing itches and lesions that may interfere in the flight. Furthermore, individuals of the genus Proctophyllodes Robin, 1877 concentrate inoffensively on the primary and secondary remiges of passerine birds (PhILIPs 1993).

According to Radford (1958) and Gaud \& Atyeo (1996) some genera of feather mites are restricted to families, genera, and even species of birds. There are few families of feather mites that are found in different orders and species of birds. Also, there is specificity for the host body region, and it is possible to find different species of mites on the same host (RADFORD 1958, Gaud \& Atyeo 1996).

In Brazil, there are few studies on the ecology of feather mites. Carvalho \& Serra-Freire (2001) studied the Astigmata mites of Ramphocelus carbo (Pallas, 1764). In addition, there are some studies that correlate the infestation level with host species biology and ecological factors (e.g. Marin et al. 1996, Marini \& Couto 1997, Roda \& Farias 1999, Neves et al. 2000). Here, it was attempted to evaluate the degree of infestation of feather mites on birds of the family Emberizidae in the Atlantic Forest of northeastern Brazil, correlating this information with seasonality and aspects of the host biology.

\section{STUDY AREA AND METHODS}

The study was carried out at the Refúgio Ecológico Charles Darwin, a 60 ha fragment of Atlantic Forest situated in the municipality of Igarassú, Pernambuco $\left(7^{\circ} 48^{\prime}-7^{\circ} 49^{\prime} S\right.$ and $\left.34^{\circ} 56^{\prime}-34^{\circ} 57^{\prime} \mathrm{W}\right)$. The area is covered by secondary vegetation, which is surrounded by monocultures such as "elephant grass" (Pennisetum purpureum). The study area is located nearby other fragments, what might explain its avifauna composition, and where big frugivores such as Trogon curucui (Linneus, 1766), and threatened species such as Iodopleura pipra (Lesson, 1831) and Touit surda (Kuhl, 1820) also occur.

The birds were captured between August 1996 and July 1997 with mist-nets opened from 6:00 throughout 17:00 h, three days a month. Upon capture, each bird was weighed, checked for the presence of incubation patch, sexed (when possible), aged, and metal banded. Feather mites were colleted by the cutting of feathers. Three samples of each bird (remiges, rectrixes, and head feathers) were collected. Mites were preserved in $70 \%$ alcoholic solution, slide-mounted, and identified at the Laboratório de Invertebrados Terrestres of the Universidade Federal de Pernambuco (UFPE) and deposited in the Laboratório de Parasitologia, Departamento de Morfolgia e Fisiologia Animal of the Universidade Federal Rural de Pernambuco.

Bird prevalence (number of individuals of hosts specimens infested with a parasite species divided by the number of hosts examined) and infestation (mean number of individuals of parasite species per host species) was evaluated (MARGOLIs et al. 1982).

Revista Brasileira de Zoologia 20 (3): 481-485, setembro 2003 
The infestation level was divided in four categories according to criteria created by the authors: I) nil, 0 individuals; II) low, 1-50 individuals; III) moderate, 51-100 individuals; and IV) high, 101-150 individuals. This information was compared with bird species sex, age, season, reproductive period, and body mass. Also, seasonal variation (wet and dry seasons) was tested for variations in infestation levels. The Chi-Square test was used to test the prevalence of feather mites and the variables mentioned above.

The weight of each captured bird was calculated across the mean, standard deviation and confidence interval. It was divided in three categories, according to criteria created by the authors. They are: weight above the medium (mean - confidence interval); medium weight (mean); weight under the medium (mean + confidence interval).

The frequency of feather mite occurrence on its hosts (number of occurrence of each mite genus divided by the total number of genus) was calculated and expressed in percentage. It was divided in four categories according to criteria created by the authors, as follows: I) absent (0); II) occasional (1-33\%); III) abundant (34-66\%); and IV) dominant (67-100\%).

\section{RESULTS}

Feather mite prevalence and infestation level were analyzed for 94 individuals of nine bird species: Tachyphonus rufus (Boddaert, 1783); Arremon taciturnus (Hermann, 1783); Ramphocelus bresilius (Linnaeus, 1766); Euphonia violacea (Bertoni, 1901); Tangara cayana (Gmelin, 1789); Thraupis palmarum (Wied, 1821); Coereba flaveola (Cabanis, 1851); Cyanerpes cyaneus (Linnaeus, 1766), and Dacnis cayana (Chubb, 1910). Of these, 92 individuals $(97,8 \%)$ were infested. The ectoparasites belonged to four families and five genera of the Analgoidea: Analges Nitzsch, 1818 (Analgidae); Mesalgoides Gaud \& Atyeo, 1967 (Psoroptoididae); Pterodectes Robin, 1877 and Proctophyllodes (Proctophyllodidae), and Trouessartia Canestrini, 1899 (Trouessartiidae). The genera with highest prevalence were Pterodectes (88,04\%), Proctophyllodes $(56,52 \%)$, and Trouessartia (45,65\%) (Fig. 1).

According to data on pluviometry, temperature, and relative air humidity, the period between September 1996 and February 1997 was defined as the dry season, and August 1996 and the period between March 1997 and July 1997 was defined as the wet season (Tab. I). The reproductive period extended from September 1996 throughout March 1997. It was determined by checking the birds for the presence of incubation patch.

The frequency of occurrence varied among the host species. Pterodectes was present in all species and was dominant only in Tachyphonus rufus $(66,7 \%)$. Proctophyllodes was abundant only in Dacnis cayana, and was occasional in the other species. Trouessartia occurred in all species, but was abundant only in Ramphocelus bresilius. Finally, Analges and Mesalgoides were occasional in all bird species. The frequency of ectoparasite occurrence is summarized in table II.

The remiges showed the highest occurrence of feather mites, followed by the rectrixes and head feathers. Pterodectes was dominant in the rectrixes and abundant in the remiges. On the head, Trouessartia was dominant. Proctophyllodes, Analges, and Mesalgoides occurred only occasionally in all body parts of the host (Tab. III).

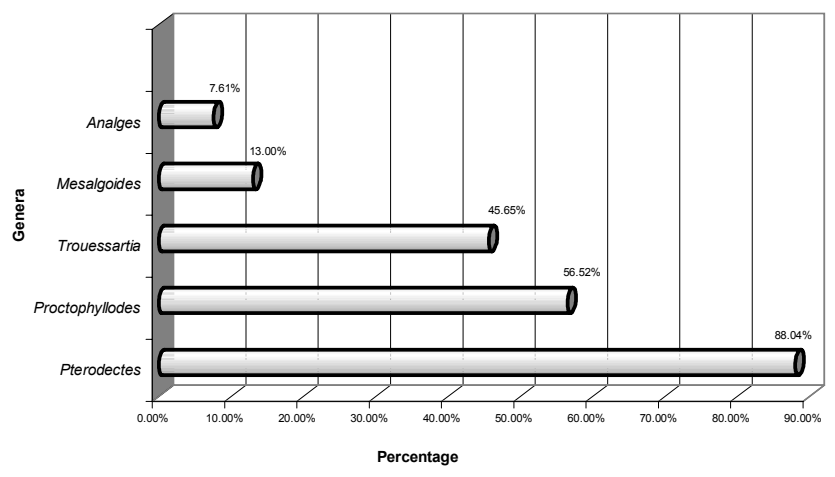

Figure 1. Prevalence of feather mite genera on birds of the family Emberizidae captured at the Refúgio Ecológico Charles Darwin between August/1996 and July/1996.

Individuals of nine bird species were captured during the dry/reproductive period. Six of them showed high infestation levels, two showed moderate levels, and only one showed a low level. Individuals of seven bird species (Tachyphonus rufus, Arremon taciturnus, Ramphocelus bresilius, Euphonia violacea, Tangara cayana, Coereba flaveola and Dacnis cayana) were captured during the wet/non-reproductive period. Two showed high infestation levels, and five showed low levels (Tab. IV). Thraupis palmarum, Coereba flaveola, Cyanerpes cyaneus, and Dacnis cayana showed high infestation levels. Tachyphonus rufus and Ramphocelus bresilius showed moderate levels and Arremon taciturnus, Euphonia violacea, and Tangara cayana showed low levels.

The adults of four species showed high infestation levels, one showed moderate level, and four showed low levels. The infestation level among juveniles, save Cyanerpes cyaneus, was high in three species, moderate in two, and low in three (Tab. IV).

Among the birds with medium weight, three species showed high levels, one showed a moderate level, and three showed low levels. Of all the birds with weight above the medium, five species showed high infestation levels, two showed moderate levels, and two showed low levels. Among all birds with weight under the medium, four species showed high infestation levels, one showed a moderate level, and four showed low levels (Tab. IV).

No remarkable difference was found between the infestation level and the age $\left(\chi^{2}=1,559 \mathrm{~N}=94 ; \mathrm{p}=0.6686\right)$, body mass $\left(\chi^{2}=8,675 ; \mathrm{N}=94 ; \mathrm{p}=0.1927\right)$, and $\operatorname{sex}\left(\chi^{2}=1.397 ; \mathrm{N}=57\right.$; $\mathrm{p}=0.7063)$ of the hosts. However, the infestation level varied significantly according to the reproductive period $\left(\chi^{2}=52,410\right.$; $\mathrm{N}=94 ; \mathrm{p}<0.0001)$, host species $\left(\chi^{2}=71,945 ; \mathrm{N}=94 ; \mathrm{p}<0.0001\right)$, and seasonal variation $\left(\chi^{2}=49,542 ; \mathrm{N}=94 ; \mathrm{p}<0.0001\right)$.

\section{DISCUSSION}

In this study, it was observed that Pterodectes was the most abundant, followed by Proctophyllodes. These data agree with Roda \& Farias (1999), who found that Pterodectes was the most abundant genus among the host species studied.

In general, feather mites are very specific to families, gen- 
Table I. Data on pluviometry, temperature, and relative air humidity during fieldwork at the Refúgio Ecológico Charles Darwin, Igarassú, Pernambuco.

\begin{tabular}{|c|c|c|c|c|c|c|c|c|c|c|c|c|}
\hline \multirow{2}{*}{ 1996/1997 } & \multicolumn{12}{|c|}{ Seasons } \\
\hline & Wet & & & & Dry & & & & Wet & & & \\
\hline Pluviometry (mm3) & 254.0 & 191.0 & 32.3 & 63.7 & 38.3 & 30.2 & 158.6 & 224.4 & 362.7 & 464.9 & 182.2 & 205.4 \\
\hline Temperature $\left({ }^{\circ} \mathrm{C}\right)$ & 24.5 & 25.1 & 26.4 & 26.7 & 27.2 & 27.7 & 27.0 & 26.8 & 26.2 & 25.5 & 24.2 & 23.9 \\
\hline Relative air humidity( \%) & 81.9 & 78.3 & 75.0 & 74.0 & 72.6 & 71.8 & 75.3 & 79.8 & 82.6 & 84.6 & 84.6 & 83.1 \\
\hline
\end{tabular}

Table II. Frequency of occurrence (\%) of feather mite genera on bird species of the Emberizidae family captured at the Refúgio Ecológico Charles Darwin between August/1996 and July/1997.

\begin{tabular}{|c|c|c|c|c|c|}
\hline & Analges & Mesalgoides & Pterodectes & Proctophyllodes & Trouessartia \\
\hline Tachyphonus rufus & & & 66.7 & 20 & 13.3 \\
\hline Arremon taciturnus & & & 40.0 & 30 & 30.0 \\
\hline Ramphocelus bresilius & & & 33.0 & 27 & 40.0 \\
\hline Euphonia violacea & & 8 & 42.0 & 17 & 33.0 \\
\hline Tangara cayana & & 16 & 37.0 & 31 & 16.0 \\
\hline Thraupis palmarum & 9 & 6 & 45.0 & 26 & 14.0 \\
\hline Coereba flaveola & 8 & 12 & 36.0 & 28 & 16.0 \\
\hline Cyanerpes cyaneus & 9 & 4 & 39.0 & 22 & 26.0 \\
\hline Dacnis cayana & & & 40.0 & 35 & 25.0 \\
\hline
\end{tabular}

Table III. Frequency of occurrence (\%) of feather mite genera on the body parts of the Emberizidae family bird species captured at the Refúgio Ecológico Charles Darwin between August/1996 and July/1997.

\begin{tabular}{lccc}
\hline \multicolumn{1}{c}{ Genera } & Remiges & Rectrices & Head \\
\hline Analges & 1 & - & 16 \\
Mesalgoides & 1 & 10 & 5 \\
Pterodectes & 50 & 73 & 3 \\
Proctophyllodes & 33 & 7 & 3 \\
Trouessartia & 15 & 10 & 73 \\
\hline
\end{tabular}

era, and even species of birds (RADFord 1958, GAUD \& ATYEO 1996). One can observe that mites of the Analgidae and Psoroptoididae families were present in Euphonia violacea, Tangara cayana, Thraupis palmarum, Coereba flaveola, and Cyanerpes cyaneus. Individuals of the Proctophyllodidae and Trouessartidae were present in all bird species. According to GaUd \& ATYeo (1996), each group of feather mites occur in different areas of the host body, forming actual microhabitats. Thus, various species are able to live in the same host without real competition. In this study, it was observed that Pterodectes was abundant in the remiges, dominant in the rectrixes, and occasional on the head, always on the ventral surface of the feather.
Proctophyllodes was abundant in the remiges, and occasional in the rectrixes and head, occupying the ventral surface of the feather. On the head, Trouessartia was dominant in the dorsal surface of the feathers. RODA \& Farias (1999) attested the presence of Pterodectes and Proctophyllodes in the ventral surface of the wing and tail feathers, and Trouessartia in the dorsal surface of the feather. Analges was found on the head and Mesalgoides was found in the dorsal surface of remiges, rectrixes, and head feathers. Generally, each feather mite species occupies a limited area of plumage, and is specific not only to a host species, but also to a region of the host body. Furthermore, it is possible to find different species of mites on the same host. The distribution of a given host species in microhabitats allows many species to live at the same host, apparently without competition (GAUD \& AтYEO 1996).

The host biomass did not interfere in the infestation increase. These results agree with the obtained by MARINI et al. (1996), who analyzed the biomass of four bird species infested by mites. These authors also did not observe a significance regarding host sex and the infestation by feather mites.

The highest infestation level occurred in the dry season and during the reproductive period. According to MCCLURE (1989), the increase of relative air humidity reduces the concentration of mites in the feather, with the increase of infestation being affected by the climatic changes. According to MarINI \& Couto (1997), the highest infestation level occurs during the rainy station (from January throughout April). In spite of the rain, this period is considered summer at the region, that is, it is 
Table IV. Infestation levels by feather mites according to the age, body mass, and sex of the bird species (Tachyphonus rufus, Arremon taciturnus, Ramphocelus bresilius, Euphonia violacea, Tangara cayana, Thraupis palmarum, Coereba flaveola, Cyanerpes cyaneus, Dacnis cayana) captured at the Refúgio Ecológico Charles Darwin between August/1996 and July/1997. (X) Species without sexual dimorphism, juvenile individuals and individuals captured during the rainy season.

\begin{tabular}{|c|c|c|c|c|c|c|c|c|c|c|c|}
\hline \multicolumn{2}{|c|}{ Parameters } & \multirow{2}{*}{$\frac{\text { rufus }}{124}$} & \multirow{2}{*}{$\frac{\text { taciturnus }}{13}$} & \multirow{2}{*}{$\frac{\text { bresilius }}{112}$} & \multirow{2}{*}{$\frac{\text { violacea }}{51}$} & \multirow{2}{*}{$\frac{\text { cayana }}{73}$} & \multirow{2}{*}{$\frac{\text { palmarum }}{105}$} & \multirow{2}{*}{$\frac{\text { flaveola }}{126}$} & \multirow{2}{*}{$\frac{\text { cyaneus }}{119}$} & \multirow{2}{*}{$\frac{\text { cayana }}{132}$} & \multirow{2}{*}{$\frac{\text { Total average }}{95}$} \\
\hline Season & Dry & & & & & & & & & & \\
\hline & Wet & 50 & 27 & 19 & 24 & 14 & $x$ & 102 & $x$ & 106 & 78 \\
\hline \multirow[t]{2}{*}{ Reproductive period } & Breding & 124 & 67 & 112 & 49 & 73 & 105 & 124 & 119 & 125 & 95 \\
\hline & Non-Breding & 50 & 16 & 19 & 6 & 14 & $x$ & 102 & $x$ & 106 & 46 \\
\hline \multirow[t]{3}{*}{ Age } & Adult & 96 & 27 & 42 & 31 & 42 & 107 & 113 & 119 & 132 & 114 \\
\hline & Juvenile & 107 & 12 & 67 & 9 & 34 & 70 & 141 & $x$ & 107 & 107 \\
\hline & Low & 93 & 12 & 18 & 37 & 16 & 106 & 130 & 135 & 122 & 108 \\
\hline \multirow[t]{2}{*}{ Mass } & Mean & 74 & 120 & 22 & 7 & 35 & $x$ & $x$ & 104 & 129 & 102 \\
\hline & High & 114 & 18 & 112 & 38 & 60 & 104 & 121 & 91 & 114 & 114 \\
\hline \multirow[t]{2}{*}{ Sex } & Male & 105 & 31 & 66 & 42 & 48 & $x$ & $x$ & 110 & 107 & 106 \\
\hline & Female & 103 & 22 & 18 & 23 & 2 & $x$ & $x$ & 138 & 130 & 117 \\
\hline Total average & & 95 & 29 & 55 & 29 & 37 & 104 & 124 & 105 & 120 & \\
\hline
\end{tabular}

the hottest period and consequently the most favorable to parasitism. However, it does not coincide with the reproductive period. MARINI \& CouTo (1997) observed that the highest infestation in the Emberizidae family occurred during the hottest period, corresponding to the summer. Thus, is concluded that the parasitical index varies with the season climatic conditions.

A remarkable variation between the host species and the infestation level was observed. According to MARINI \& Couto (1997), frugivorous and nectarivorous species are more susceptible to infestations by feather mites. Moreover, the nest types and the presence in mixed-species flocks can also affect the infestation levels. In this study was observed that Coereba flaveola, Cyanerpes cyaneus, and Dacnis cayana, which feed on nectar, were the birds with the highest infestation level. The only frugivorous observed, Thraupis palmarum, showed a high level.

Despite the size of the study area, which is a small forest fragment ( $60 \mathrm{ha})$, the results are relevant and reinforced by the results of other authors, which undertook studies in larger areas. According to MARINI (2000), the fragment size does not interfere in the infestation by ectoparasites in birds.

\section{ACKNOWLEDGMENTS}

We thank the Mestrado de Biologia Animal of Universidade Federal de Pernambuco, and the CAPES for the financial support. We also thank Roberto Siqueira (Refúgio Ecológico Charles Darwin) and Magnólia Nunes Botelho (Laboratório de Parasitologia, UFRPE) for the help provided during our work.

\section{REFERÊNCIAS BIBLIOGRÁFICAS}

Carvalho, A.R. de \& N.M. Serra-Freire. 2001. Identificação de ácaros Astigmata encontrados em penas de pipira-do-papo- vermelho (Ramphocelus carbo) em Belém, Pará, Brasil. Tangara, Belo Horizonte, 1 (2): 85-87.

GAUD, J. \& W.T. ATyeo. 1996. Feather mites of the world (Acarina, Astigmata): the supraspecific taxa. Part. I. Annales Musee Royal L'Afrique Centrale, Sciences Zoologiques, Tervuren, 277: 1-187.

Margolis, L.; G.W. Esch; J.C. Holmes; A.M. Kuris \& G.A. Schad. 1982. The use of ecological terms in Parasitology (Reported of an ad hoc Committee of the American Society of Parasitologists). Journal of Parasitology, Cambridge, 68 (1): 131133.

MarinI, M.A. 2000. Efeitos da fragmentação florestal sobre as aves em Minas Gerais, p. 41-54. In: M.A. dos S. Alves, J.M.C. da Silva; M.S. Sluys; H. de G. Bergallo \& C.F.D. da Rocha (Eds). A Ornitologia no Brasil, pesquisa atual e perspectivas. Rio de Janeiro, Eduerj, 351p.

Marini, M.A.; B. L.Reinert; M.R Bornschein; J.C. Pinto \& M.A. PICHORIM. 1996. Ecological correlates of ectoparasitism on Atlantic Forest birds, Brazil. Ararajuba, Belo Horizonte, 4: 93-102.

Marini, M.A. \& D. Couto. 1997. Correlações ecológicas entre ectoparasitas e aves de florestas de Minas Gerais, p. 210218. In: L.L. Leite \& C.H. SAITO (Eds). Contribuição ao conhecimento Ecológico do Cerrado. - Trabalhos selecionados do $3^{\circ}$ Congresso de Ecologia do Brasil. Brasília, Departamento de Ecologia, Universidade de Brasília, 325p.

McClure, H.E. 1989. Occurrence of feather mites (Proctophyllodidae) among birds of Ventura County Lowlands, California. Journal of Field Ornithology, Camarillo, 60: 431450.

Neves, R.M.L.; A.M.I. de Farias; W.R. Telino Júnior; M. Arzua; M.C.N. Botelho \& M. DA C.A. E Lima. 2000. Ectoparasitismo 
em aves silvestres (Passeriformes - Emberizidae) de Mata Atlântica, Igarassu, Pernambuco. Melopsittacus, Belo Horizonte, 3: 64-71.

Philips, J.R. 1993. Avian mites. Compendium on Continuing Education for the Practicing Veterinarian, Montreal, 15: 671-683.

Received in 25.III.2003; accepted in 20.VIII.2003.
RADFORD, C.D. 1958. The host-parasite relationships of the feather mites (Acarina: Analgesoidea). Revista Brasileira de Entomologia, São Paulo, 8: 107-170.

RodA, S.A. \& A.M.I. Farias. 1999. Ácaros plumícolas em aves Passeriformes da Zona da Mata Norte de Pernambuco, Brasil. Revista Brasileira de Zoologia, Curitiba, 16: 879-886.

Revista Brasileira de Zoologia 20 (3): 481-485, setembro 2003 